\title{
Community-Based Business on Small Hydropower (SHP) in Rural Japan: A Case Study on a Community Owned SHP Model of Ohito Agricultural Cooperative
}

\author{
Zafar Alam ${ }^{1}$, Yoshinobu Watanabe ${ }^{1}$, Shazia Hanif ${ }^{2}$, Tatsuro Sato ${ }^{3}$ and Tokihiko Fujimoto ${ }^{4, *}$ \\ 1 Nakayama Iron Works Co. Ltd., Saga 843-0001, Japan; zafar_a@nakayamairon.co.jp (Z.A.); \\ watanabe@nakayamairon.co.jp (Y.W.) \\ 2 Department of Agricultural Engineering, Muhammad Nawaz Sharif University of Agriculture, \\ Multan 66000, Pakistan; shazia.hanif@mnsuam.edu.pk \\ 3 Faculty of Architecture and Civil Engineering, Kyushu Sangyo University, Fukuoka 813-8503, Japan; \\ sato@ip.kyusan-u.ac.jp \\ 4 School of Political Science and Economics, Meiji University, Tokyo 101-8301, Japan \\ * Correspondence: fujimoto@meiji.ac.jp
}

check for

updates

Citation: Alam, Z.; Watanabe, Y.; Hanif, S.; Sato, T.; Fujimoto, T.

Community-Based Business on Small Hydropower (SHP) in Rural Japan: A Case Study on a Community Owned SHP Model of Ohito Agricultural Cooperative. Energies 2021, 14, 3349. https://doi.org/10.3390/en14113349

Academic Editors: John M. Cimbala and Bryan J. Lewis

Received: 14 May 2021

Accepted: 4 June 2021

Published: 7 June 2021

Publisher's Note: MDPI stays neutral with regard to jurisdictional claims in published maps and institutional affiliations.

Copyright: (c) 2021 by the authors. Licensee MDPI, Basel, Switzerland. This article is an open access article distributed under the terms and conditions of the Creative Commons Attribution (CC BY) license (https:// creativecommons.org/licenses/by/ $4.0 /)$.

\begin{abstract}
Energy is the prerequisite for social and economic development of a community and country. In Japan, national government is promoting small hydropower (SHP) through a renewable energy policy by providing a high FIT price of 34 yen $(=0.32 \mathrm{US} \$ / \mathrm{kWh})$ on energy generated from an SHP of less than $200 \mathrm{~kW}$. Until now, the energy generation was controlled by national government agencies, but now independent power generation businesses are growing at the local community level in rural Japan. For the future growth of SHP, it is necessary to make electricity generation at the local community level. Therefore, these local communities will install and manage their renewable electricity by themselves. It will help to make the community self-sustainable and independent from the national government, and at the same time, it will also lead them to achieve the Sustainable Developments Goals (SDGs) target from community-based action. This paper aimed to discuss an SHP development business model in which local community will become the business owner of the SHP. It means "of the community, by the community and for the community". The community identifies their renewable energy potential and needs, they borrow money from the financial organization or banks, install the power plant and do necessary maintenance and management by themselves. The revenue earned by selling electricity is used to repay the loan, and the rest is used for community development directly (such as local roads construction, agriculture land improvements, community hall maintenance, waterways maintenance, welfare, etc.). This paper also discussed a community-based $50 \mathrm{~kW}$ SHP installed in Miyazaki prefecture of Japan as a case study. This SHP is one of the best examples of a community ownership model (Community-based business model). A detailed explanation from planning to investment has been discussed. The local community is getting approximately 112,000 USD per year by selling the electricity, and 162-ton $\mathrm{CO}_{2}$ is estimated to decrease yearly, which will support the achievement of SDGs. Finally, installing this kind of SHP in remote areas will provide managerial skills to the local community directly, plant operation knowledge, and education to local students. Local communities learn the problem-solving skills, which lead them to solve the local problem on a community level by themselves.
\end{abstract}

Keywords: community development; community ownership; small hydropower; SHP; renewable energy; crowdfunding; FIT; community-based business; agricultural cooperative

\section{Introduction}

In the present scenario, increasing world energy demand and climate change imperatives drive the dependency of energy sources towards available renewable energy resources. Climate change is one of the major factors that has a strong impetus on the 
way of thinking about world energy dependency. It urges the world to achieve alternative renewable resources other than its reliance on fossil fuels. In this regard, it is not only requisite to use all the possible renewable resources, but also to shift the established fossil fuel-based energy system toward renewable energy. Therefore, it is necessary to exploit domestic energy sources, especially renewable energy sources, as their potential is high.

Moreover, for UN- Sustainable Development Goals (SDGs), it is required for a country to devise policies and form strategies to increase the share of renewable energy in the total energy mix, and ensure the provision of electricity to the rural and remote areas. In rural areas, there are a variety of renewable energy options available, e.g., hydropower, solar, wind and biomass. Many mathematical models have been used to make decisions among all available renewable energy resources. Geological position and terrain are characterized as strong impact for the assessment of most suitable renewable energy resources, e.g., in Brazil, wind energy is considered the most favorable renewable energy source [1]. In addition, environmental and human health impacts are also very important consideration for the selection [2].

Being a target part of SDGs, sustainable supply chain management is prerequisite for the modern world in order to conserve the available resources, reduce the waste as well as generate revenue. It not only helps the natural environment, but it can also give enterprises financial benefits [3]. In addition, their efforts can be more effective if integrated approach and regional networking are involved [4]. Many researches highlight the constraints and barriers related to the implementation of SDGs in supply chains. For sustainable development, organizational management is responsible for dealing with social, economic as well as ecological performance at the same time. However, sometimes implementation of the goals is associated with enormous problems, which deject the continuity of work and ultimately discourage business managers [5]. The purpose of renewable energy is not only to raise the rural economy, but also to save the ecological environment [6]. The main objective of sustainable development is to provide better life to human beings by wise utilization of the natural resources and considering its limitations on the one Earth [7].

Small hydropower (SHP) is considered a reliable and sustainable source for making electricity. As a potential future source of energy, it has become an increasingly attractive choice, which plays an important role for its adoption and development all over the world. It is considered environmentally friendly, as its construction has small effects on water bodies. SHP gain more preference because of its available potential, small scale construction requires less investment, speedy construction, low cost generate quick revenue as well as environmentally friendly clean energy $[8,9]$. The other benefits are to reduce the safety risks associated with small dams, and lesser population displacement or land usage issues [10]. Small hydropower does not require a large storage structure like dam construction as compared to large scale hydropower, thus reducing the technology's environmental impacts [11]. For SHP, potential power available, head, and flow considerations are very important constraints regarding the selection of site-specific parameters [12]. Sites with a reliable water supply year-round and a large vertical drop in a short distance are considered as the best locations for the installation of SHP.

In Japan, hydroelectricity is considered the second most important renewable energy source after solar energy. There are several reports regarding the economic benefits of implementing SHP, considering ecological sustainability and environmental ecosystem, and their impacts [13-16]. Overall, Japan has an abundance of small streams particularly in mountainous regions and in the past many small channels have been created for irrigation purposes. Some of these irrigation channels continue to be used today. Others, though in good condition, remain unused. Increasingly, these channels are being utilized to produce SHP electricity to promote local development. This is particularly important for rural Japan, which has suffered from rapid depopulation due to a combined effect of aging population and urban migration [17].

Small hydropower has regained attention in Japan since the 2000s, when climate change and climate crisis were highlighted. In 2003, the "Act on Measures Concerning the 
Use of New Energy by Electric Power Companies" (RPS Act) targeted small hydropower of $1000 \mathrm{~kW}$ or less, so that about 10 new construction works will be carried out annually. The RPS Law was taken over by the "Act on Special Measures Concerning the Procurement of Renewable Energy Electricity by Electricity Companies" (commonly known as the FIT Law) in 2012, and under the feed-in tariff (FIT); in recent years, the small hydropower market has been gradually revitalizing. The Japanese government has started to support the SHP project in order to support a renewable policy in Japan as well as to prevent migration and to protect the old rich culture of the respective communities [18].

To promote the SHP, the Japanese government is giving a high FIT of 34 yen per $\mathrm{kWh}$ $(=0.32 \mathrm{US} \$ / \mathrm{kWh})$ under the capacity of $200 \mathrm{~kW}$, which enables a faster payback $[18,19]$. In spite of FITs and other benefits, planning a new SHP plant, searching for the initial investment, consensus building among the community people and various stakeholders, convincing local people is not an easy task and so, and despite having hydro potential in a number of communities, it has not been harnessed yet. This paper will discuss an ongoing business model idea to develop community-based SHP in rural areas, which is based on:

- Of the community;

- $\quad$ By the community;

- For the community.

In Japan, the concept of community development by SHP installation is not new. A number of SHP were installed in 1940-1970. In Japanese remote areas, many SHP run by local agricultural cooperatives (hereinafter referred to as agricultural cooperatives) exist in the Chugoku region in the west part of the main island in Japan. By the end of March 1955, about 90 SHP operated by agricultural cooperatives and others were built in the Chugoku region, while 181 were constructed nationwide. To this day, some facilities were abolished or suspended due to disaster, aging, poor management, submergence and other reasons. By 1980, 74 remained, and currently 54 are still generating. All 54 facilities currently in operation are less than $1000 \mathrm{~kW}$, with a maximum of $660 \mathrm{~kW}$, a minimum of $24 \mathrm{~kW}$, and an average of $189.1 \mathrm{~kW}$. The total installed capacity of the 54 facilities is $10,209 \mathrm{~kW}$ [20,21].

The purpose of this study is to provide a SHP development business model in which local communities come forward for organizing and development of SHP and become the business owner. This paper consists of three sections: the very first section explains a community owned SHP development model. It gives an idea of community ownership to develop an SHP. This section also discusses the project financing, multi-stoke holder, crowd funding, etc., with regard to SHP development. It provides an example of community development that will work collaboratively for common goals. It is expected that community level SHP development will lead to many more SHP. The second section of this paper is analyzing a case study of a community owned SHP installed in rural Japan. This section explains techno-economic details of installed SHP and its social and economic impact on community and environmental impact on climate change. The third section discusses its effects, followed by the conclusion and limitations.

\section{Community Owned SHP Development Model}

This section explains community development by installing SHP, as a communitybased business by local people.

In this model, the local residents will become business owners, it creates jobs locally, and it motivates young people to work in their hometown. Additionally, it will attract the migrated peoples from urban areas to do business in their hometown again (called $U$ turn). The installation of this kind of project intends to solve local problems by utilization of local resources. It aims to build a better relationship between urban consumers and energy production areas [22].

Step1-The identification of SHP potential, feasibility study of the potential sites must be done by the local government or prefectural government with help from a consultant, developer or NGOs of SHP. There should be consensus building between the local community, local and prefectural government and the developer, consultant or NGOs. The 
consultant should explain the benefits of installing this project to the local community by organizing seminars and consensus building meetings. In most of the cases, the local community people wish to install SHP projects, but they have some concerns about project execution, management and investment. Community people need moral support and training for fundraising, management and operation.

Step2-It is about finding low interest rate investors. In Japan, for an individual person, getting a loan from the bank or any finance is difficult. Additionally, the interest rate is quite high. However, if a community corporation needs a loan for communal use, they can get it easily. Moreover, if the corporation or company comprises farmers, then the interest rate is very low due to its social impact. To avail this opportunity, a local cooperatives and community-based business company are made, and the local people become the owner and members of this community-based business association. This new cooperative association gets the loan from the bank or financial institution and becomes the SHP project owner. In the future, this association will pay the loan, do the necessary maintenance, and utilize the revenue for the community development directly. All members of this association will be the owner of the SHP project at the community.

Step3-Community-based business model (community ownership, multistate holders, networking and various responsibilities) represents the network in which cooperative associations collaborate with the stakeholders, construction companies, consultants, mechanical and electrical makers of SHP. Cooperatives comprise individuals with mutual resources to provide input, output, and capital resources to members at a low cost.

Figure 1 represents the business flow for community SHP development projects. This networking strives to provide information and support for sustainable agriculture and community development. It develops mechanisms to monitor, promote public-private partnerships (PPP), improve smallholder agriculture, and reduce agricultural losses. Funding comes from voluntary contribution, development banks, and other local resources.

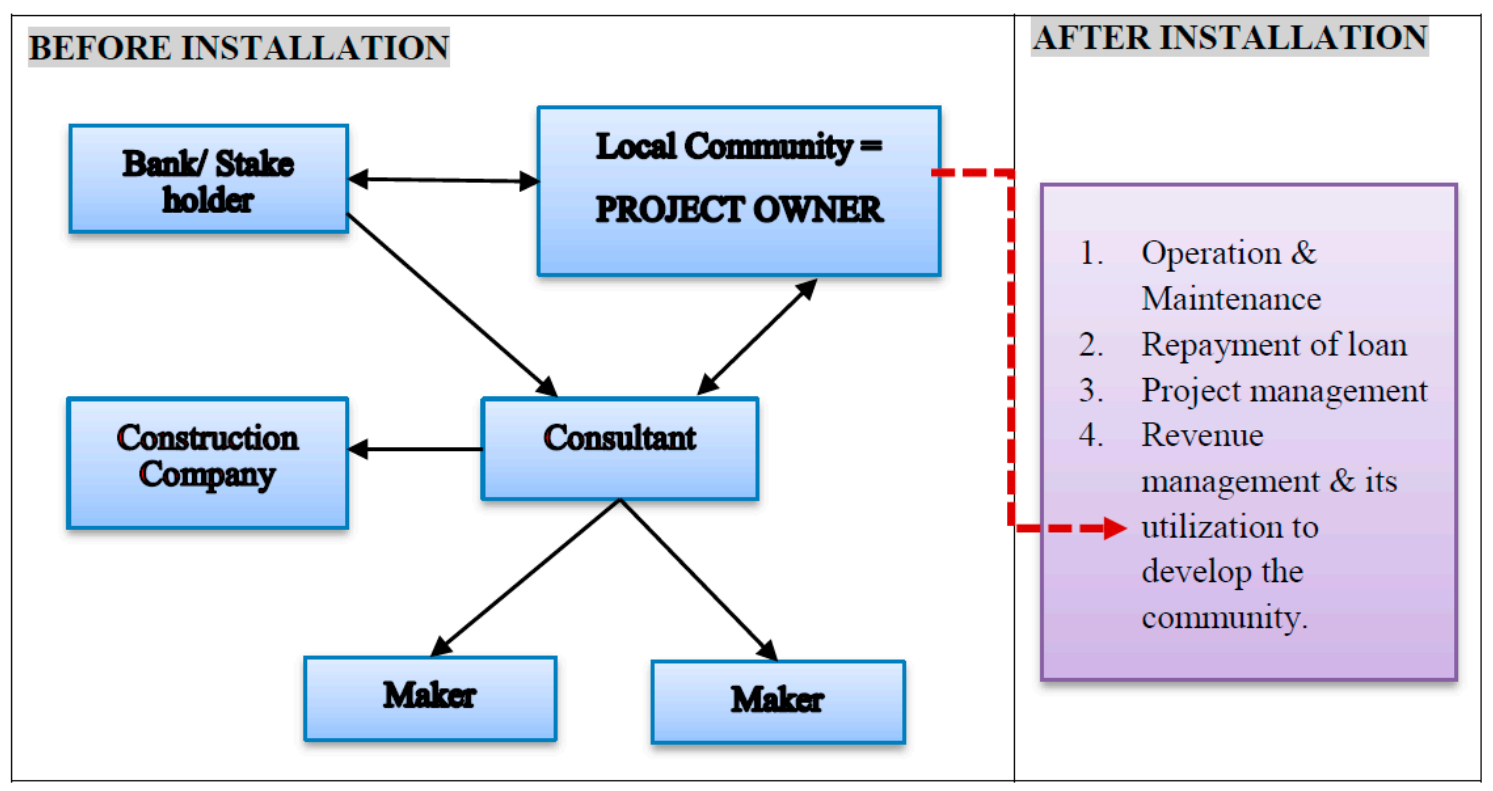

Figure 1. Community-based business model of SHP; stakeholder assigned before and after the project installation (Source: Author).

Figure 2 represents the responsibilities of each stakeholder toward development and execution of the project. It shows the strong initiative and struggle done by the local community for self-sufficiency in energy production. It also encourages the community to manage its available renewable energy resources along with local commons [23]. 


\section{RESPONSIBLITIES}

\begin{tabular}{|c|c|c|c|c|}
\hline Local comm & ity (Project owner) & Stake holder & Consultant & Maker \\
\hline $\begin{array}{l}\text { Before project } \\
\text { completion } \\
\text { i. Water rights } \\
\text { ii. Building } \\
\text { consensus } \\
\text { iii. Land lend }\end{array}$ & $\begin{array}{l}\text { After the project } \\
\text { installation } \\
\text { i. Payment to } \\
\text { stakeholders } \\
\text { ii. Maintenance of } \\
\text { power house } \\
\text { iii. Invest in local and } \\
\text { community } \\
\text { development } \\
\text { iv. Project owner }\end{array}$ & $\begin{array}{l}\text { Give loan/ or } \\
\text { borrow money } \\
\text { for local and } \\
\text { community } \\
\text { development }\end{array}$ & $\begin{array}{l}\text { i. Manage project } \\
\text { ii. Search for } \\
\text { equipment maker } \\
\text { iii. Bridge for local } \\
\text { community, } \\
\text { government, maker, } \\
\text { other stake holder. } \\
\text { iv. Evaluate the } \\
\text { merit and demerit of } \\
\text { the project }\end{array}$ & $\begin{array}{l}\text { i.Manufacturing } \\
\text { and installation } \\
\text { ii. Quality } \\
\text { Contrall }\end{array}$ \\
\hline
\end{tabular}

Figure 2. Responsibilities of each stakeholder of the project (Source: Author).

In this kind of SHP development project initiated by the community, it is necessary to utilize the local resources as much as possible. Generally, local civil companies do the civil engineering parts, locally available construction material would be used to make the powerhouse and local labor. This helps to boost the local economy and job opportunities to local people.

\section{A Case Study of $50 \mathrm{~kW}$ Ohito SHP Installed in Miyazki Prefecture, Japan}

This section discusses with the case study of the development of $50 \mathrm{~kW}$ Ohito small hydropower plant. This SHP has been installed in Ohito agricultural cooperatives owned by residents. Figure 3 shows the location map of Ohito SHP, which comes under Hinokage town in Miyazaki Prefecture. As per 1 October 2019 data, the estimated population of Ohito community is 3656 people (men and women). The total field area is $277.67 \mathrm{~km}^{2}$. It is located next to the historically significant town of Takachiho. Hinokage town is known primarily for its three large modern bridges, traditional Kagura dances, and the work of Kazuo Hiroshima, a traditional weaver of bamboo baskets.

Like many districts in rural Japan, the area has been struggling with an aging population and an exodus of young people to Tokyo and other major cities in Japan. The Hinokage town's population peaked in the 1950 s at 16,199 people, but has steadily declined since the closure of the Mitate mine in March 1970. Between 2000 and 2005, four area elementary and middle schools were closed, and more closures are planned very soon. 


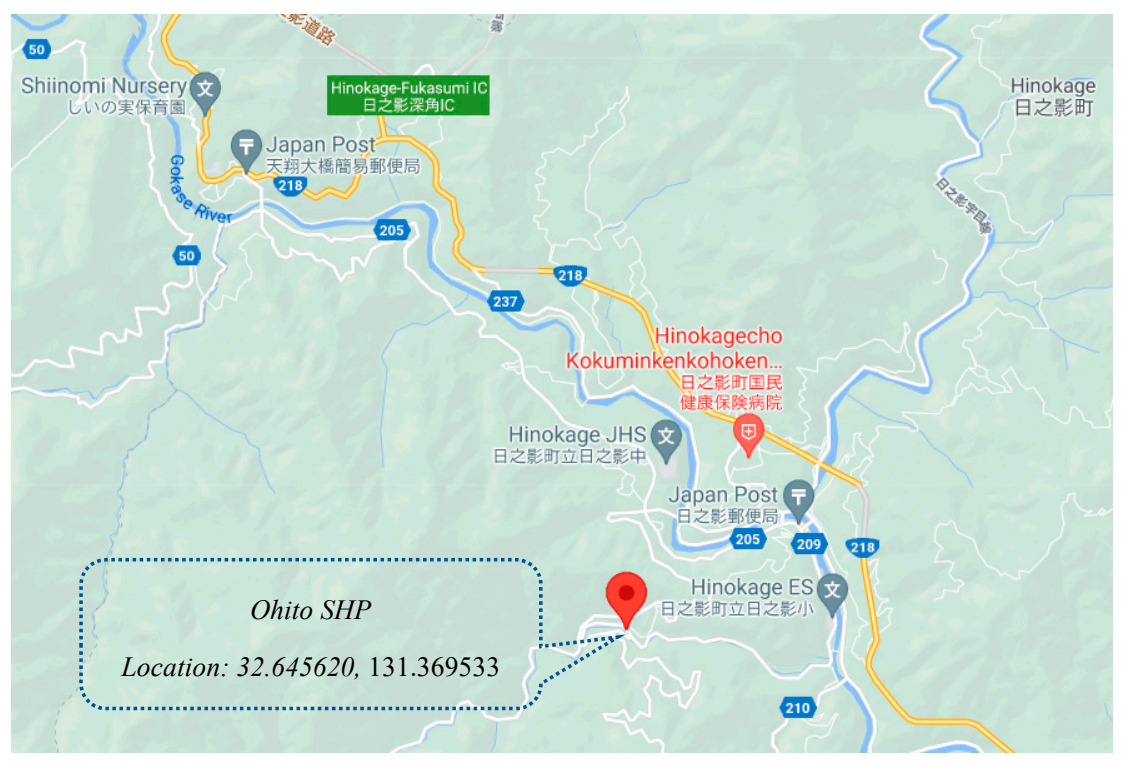

Figure 3. Location map (Source: Google map).

\subsection{Ohito SHP Development Model (A Community Ownership Concept)}

The Ohito SHP project has been started with the participation and collaboration of the local people inside the community. Firstly, the Ohito community identified the problems through which they were suffering (for example, depopulation, unavailability of local jobs, inaccessibility of electricity and other facilities and detachment from the big city). They wanted to utilize the extra water of an existing irrigation in the community, which is used for irrigation of nearby crops. The main crops are paddy, which uses a high amount of water for 4 months in a year, but for the remaining 8 months, the water was wasted at the time.

To build SHP, all the community residents jointly made a community-based business company named "Ohito Agricultural Cooperatives". There are 53 households in the Ohito community, each household becoming a member of this newly established association.

Figure 4 represents the formation structure and contribution of Ohito Agricultural Cooperatives for installing Ohito SHP. All households of the Ohito community contributed a capital amount of $4000 \mathrm{JPN}$ yen ( $=38$ USD) to establish Ohito Agricultural Cooperatives. It tries to take care of all of the community problems of mutual concerns regarding water rights and growing of a new variety of crops. It makes the village not only self-sufficient in electricity demand, but also provides handsome annual earnings. This co-operative takes all the responsibilities before and after the execution of the SHP project; maintenance of the water way and powerhouse, loan instalment payment and water use cost. The major responsibility of the organization is community development, management of financial resources, capacity building and management of the facility.

Ohito Agricultural Cooperatives uses the expertise of staff and other professionals to execute the project and data that aid development. This mobilizes and manages the funds, loans and subsidies provided by local residents, Miyazaki prefecture and banks to make sure the projects achieve their goals, respectively. It is also included in the responsibilities of the co-operatives to protect rural livelihoods, advance farming and uplift the living standards of locals. 


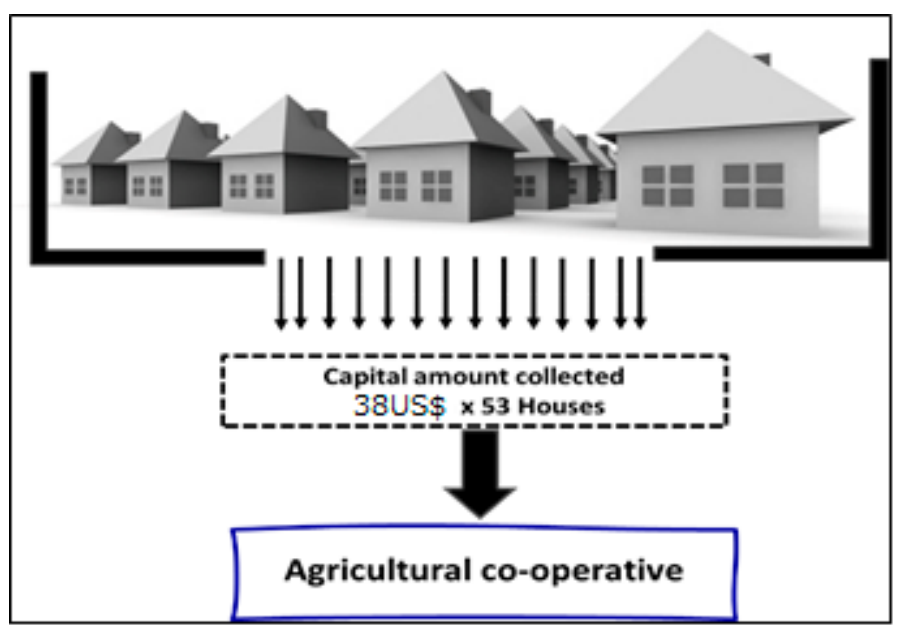

Figure 4. Formation of Ohito Agricultural Cooperatives (Source: Author).

\subsection{Technical Specification of Ohito SHP}

Total installed capacity of Ohito SHP is $50 \mathrm{~kW}$ and an annual power generation of approximately $320 \mathrm{MWh}$ /year was estimated. This SHP plant contains an irrigation channel/intake/forebay tank. Figure 5 shows the powerhouse of Ohito SHP. The powerhouse is made up of locally available stone to save money and involve the local resources. The generated electricity is sold to the national grid and it is connected to $200 \mathrm{~V}$ poles available near the powerhouse. The total length of this channel is $10 \mathrm{~km}$. At the middle of this channel (approx. $5 \mathrm{~km}$ ), a small desilting tank with a tyrolean type intake weir has been made as shown in Figure 6. The water was first stored in a forebay tank. Since the priority is given to irrigation. The rest water is utilized to produce electricity, and so the amount of discharge changes throughout the season according to water requirements for the crops.

For this site, a cross flow turbine (made in Indonesia by Asosasi Hidro Bandung) has been selected with electrical equipment and a control panel (made in Japan). A high efficiency IPM generator with AC-DC converter (GD) and further on DC-AC converter (GC) have been installed as shown in Figure 7. It is a unique system that increases the system efficiency even on low output and low speed of the generator. An IPM generator is a high efficiency $(\sim 95 \%)$ varying speed generator, which is approx. $80 \%$ efficient at $25 \%$ of its rated speed. The combination of GD and GC helps to stabilize the output voltage and frequency according to the grid requirement.

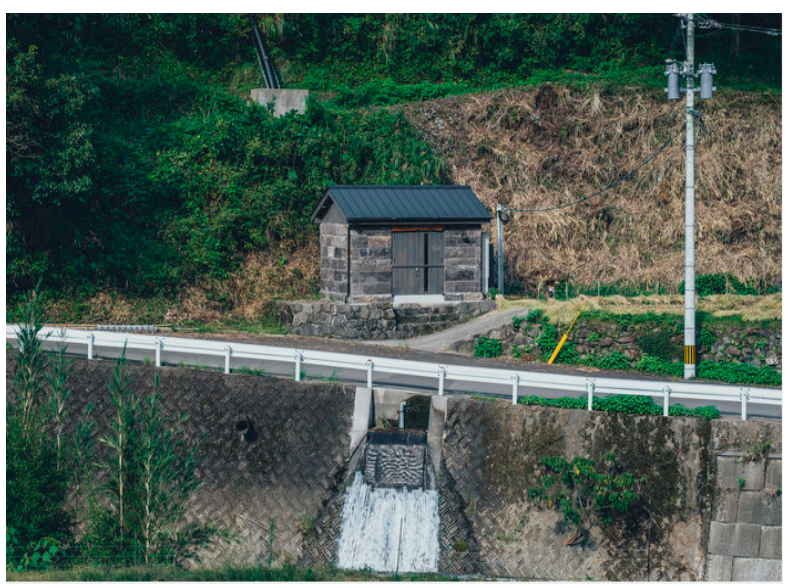

Figure 5. Power house (Source: Author). 


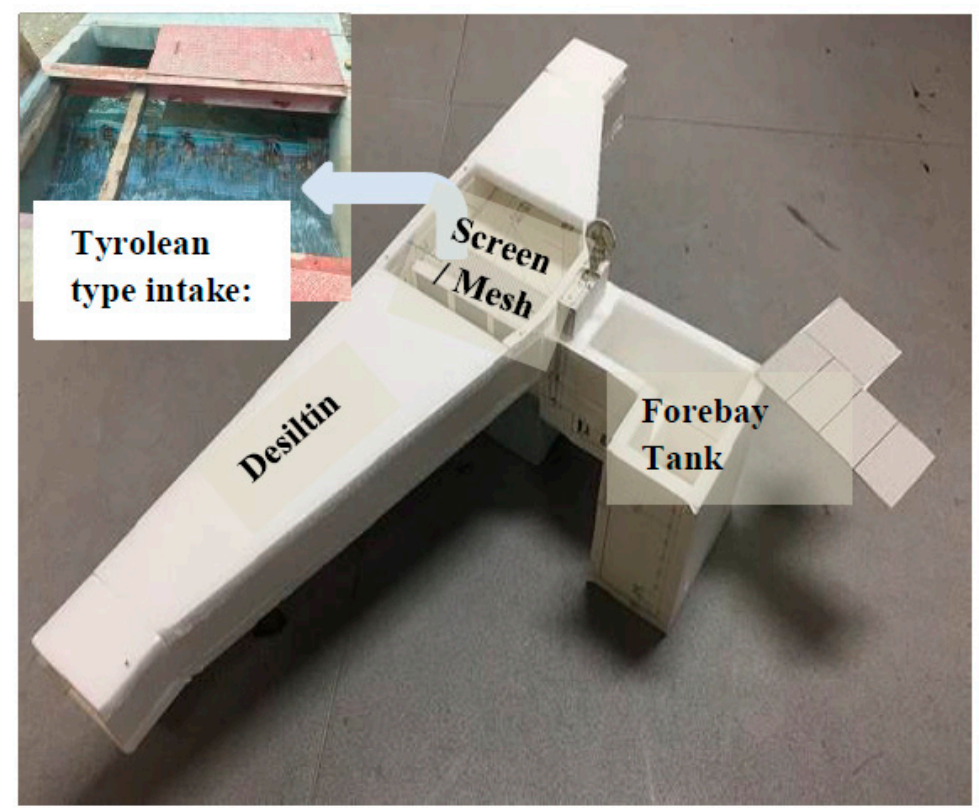

Figure 6. Tyrolean intake with forebay tank (Source: Author).

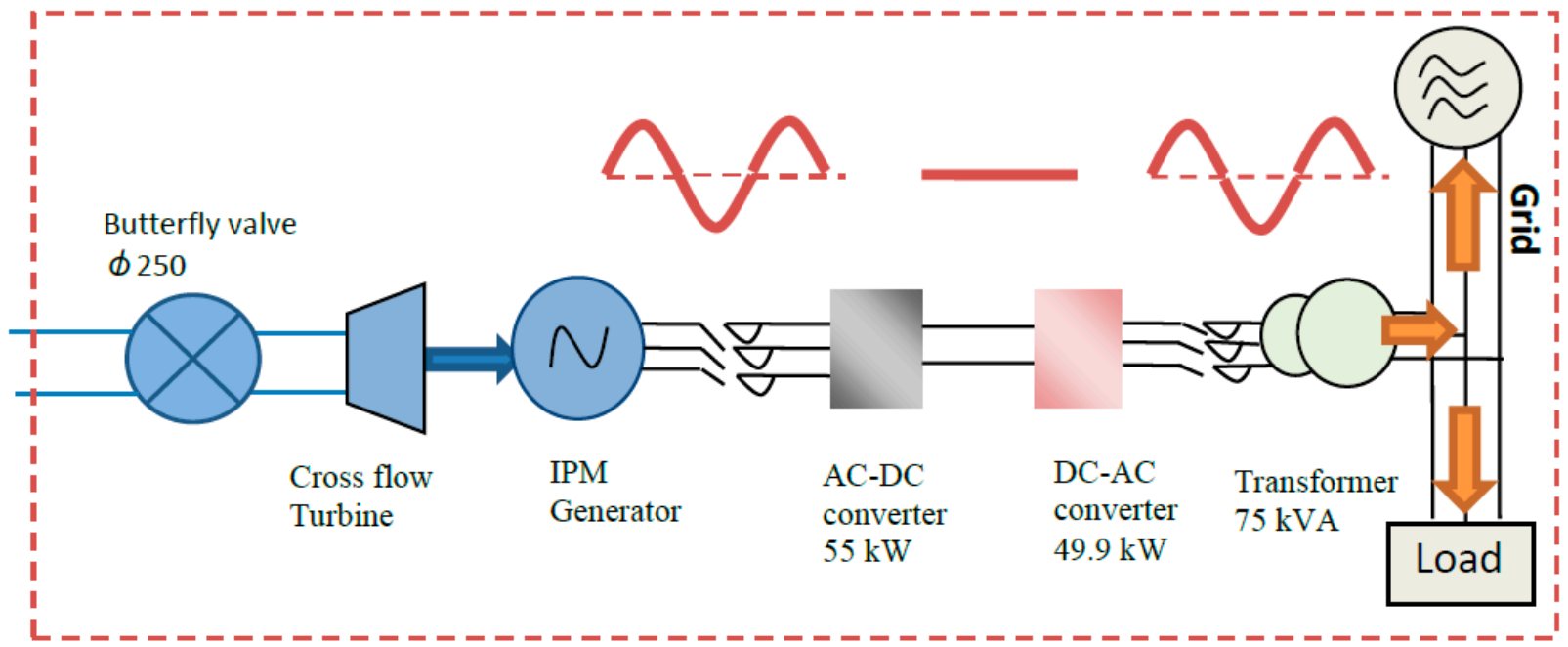

Figure 7. System flow of Ohito SHP (Source: Author).

Table 1 presents the site details and equipment specification installed at $50 \mathrm{~kW}$ Ohito SHP. The low cost overseas turbine makes the system cheaper, and a high efficiency electrical system, especially on low load condition, is an attractive concept for other similar community development projects. In a case of SHP construction in Japan, one of the major concerns is a garbage removal process. Due to low capacity, it is not economically beneficial to use an automatic garbage removal system by Tyrolean intake. Another obstacle arises due to powerhouse location (generally in mountainous regions away from the downtown). Someone must go and clean the garbage daily, it costs time, money and effort for garbage removal activities. Keeping that in mind, a Tyrolean type automatic garbage cleaning intake has been constructed. 
Table 1. Technical details of the $50 \mathrm{~kW}$ Ohito SHP (Source: Author).

\begin{tabular}{ll}
\hline Site Condition and Parameters & \\
\hline Effective head & $85 \mathrm{~m}$ \\
Design discharge & $0.12 \mathrm{~m}^{3} / \mathrm{sec}$ \\
Turbine & Cross-flow T15 (D300, B100) from Asosiasi Hidro Bandung (Indonesia) \\
Efficiency of turbine & $76 \%$ \\
Type of generator & IPM generator from Yasukawa Electronics (Fukuoka, Japan) \\
Generator specification & $1150 \mathrm{rpm}, 55 \mathrm{~kW}$ Generator + GD + DC efficiency $=\sim 94 / 95 / 95 \%$ \\
Consultant & River Village Co. Ltd. (Fukuoka, Japan) \\
Mechanical \& electrical design concept & Nakayama Iron Works Co. Ltd. (Saga, Japan) \\
Civil Engineering & Local constructor (Ohito, Miyazaki, Japan) \\
\hline
\end{tabular}

\subsection{Project Financing E Economic Parameters}

The Ohito Agricultural Cooperatives borrowed the loan from financing cooperation and banks. At the same time, they got a subsidy from the Miyazaki prefectural government. Figure 8 represents the construction cost and finance arrangement for the construction. The total cost of construction was USD 896,000. Out of which, USD 94,340 is subsidized by the government of Miyazaki prefecture. The others are arranged by the loan from the local bank of Miyazaki and Japanese Financing Corporation at the rate of interest $2.6 \%$ and $0.9 \%$, respectively, within the repay period of 20 year, which is guaranteed by FIT.

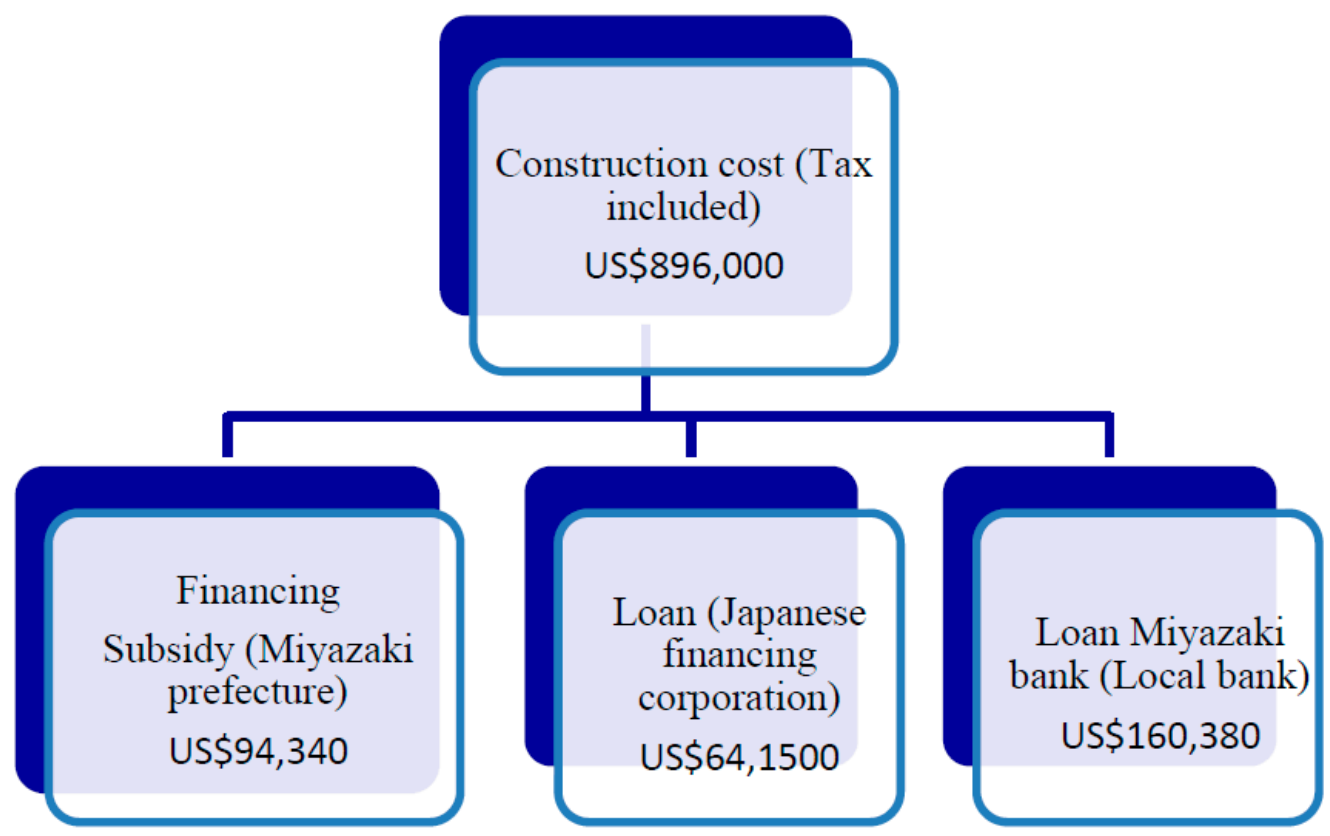

Figure 8. Business model and finance distribution for the construction of Ohito SHP (Source: Author).

Figure 9 represents a cumulative cash flow estimation of Ohito SHP. The running cost was calculated as approximately USD 8500 per year. The results of economic calculation are as follows: Project IRR (4.3\%), B/C ratio (1.36) and project payback period (13 years). In Figure 8 , the $x$-axis shows the period. Since the FIT provided by the Japanese government ended for 20 years. The cost analysis was done for a 20 years period. The $Y$-axis gives the cumulative cost per year, which includes total earning-maintenance cost-loan payment per year. The breakeven will be achieved after 13 years by the calculation. 


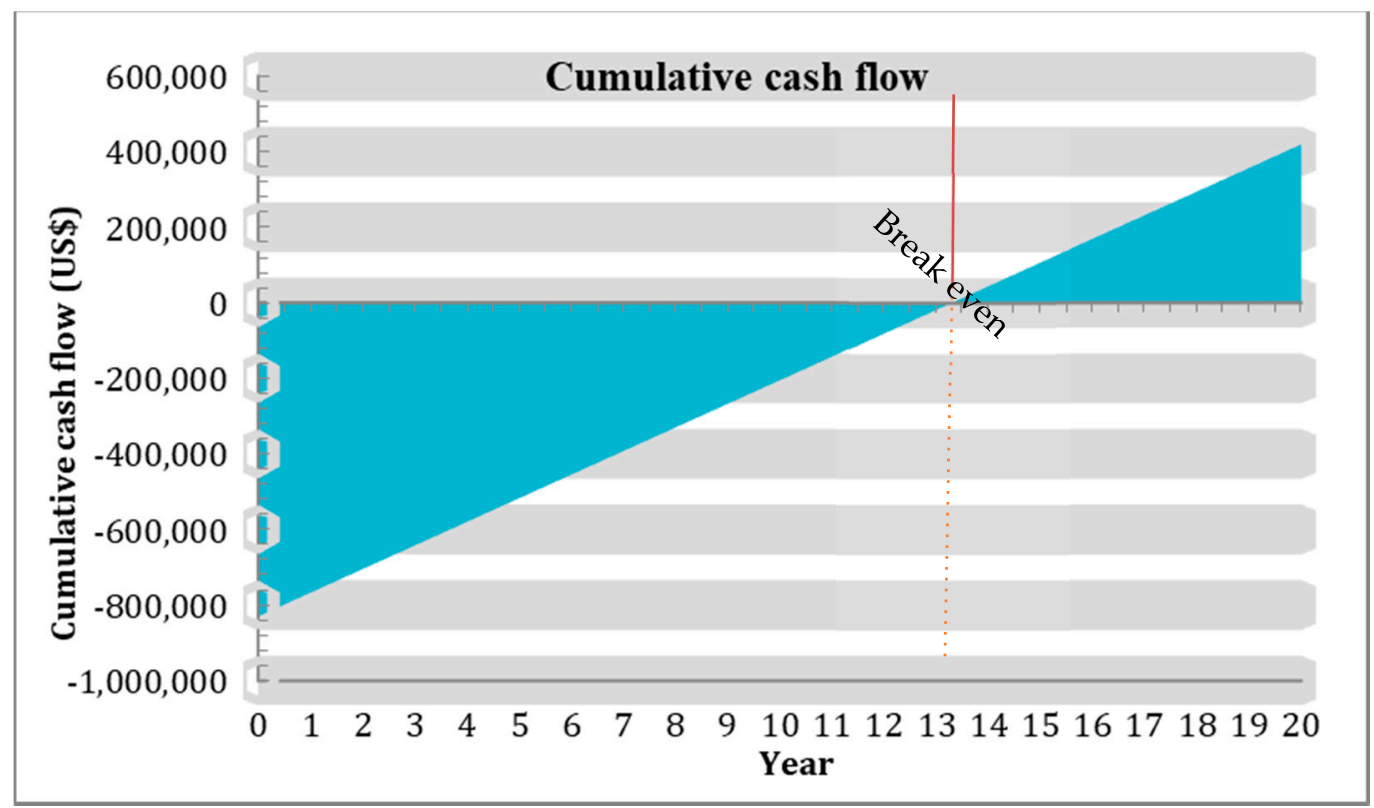

Figure 9. Cumulative cash flow of Ohito SHP (Source: Author).

\section{Discussion}

Installing SHP has several recognizable benefits, including in achieving SDGs from community-based action, and helping in the development of local community people or rural areas, which have limited jobs and facilities.

More precisely, it supports the growth of rural communities and local developers. In the case of Ohito SHP, a local civil engineering company performed all the civil works, local traditional stones and wood were used to build the powerhouse. Furthermore, community people get the benefit by selling electricity to the Kyushu Electric Power Co., Inc., Fukuoka city, Japan (one of national electric power companies), and local companies get work orders, which helps them. As discussed above, the Japanese government gives high FIT by a renewable energy policy, and the FIT provided on SHP of less than $200 \mathrm{~kW}$ is 34 yen (US\$ 0.32 per $\mathrm{kWh}$ ) for 20 years, which means an SHP developer gets high earnings by selling electricity generated from SHP.

From the economic point of view, Ohito SHP generates more than $350 \mathrm{MWh}$ per year. It continuously runs at its full capacity of $50 \mathrm{~kW}$, except for a few months during rice crop harvesting ( 4 months in a year), during that, capacity reduces to $20 \mathrm{~kW}$. The plant started in January 2018 and within the last approximately 3 years, 1100 MWh energy has been generated as per the data seen on 3 March 2021. The total revenue earned until the mentioned date was $=1100 \times 1000 \times 0.32($ FIT price $)=352,000 \mathrm{US} \$$. On average, $350 \mathrm{MWh}$ energy has been generated in the last 3 years. If the plant runs similarly as now, it is possible that the developer will achieve the breakeven point sooner than estimated.

The energy output and power generation for the last month of 10 April 2021 to 10 May 2021 is shown in Figures 10 and 11. It shows the variation of power output and power generation with the time. It shows that power output and energy generation was constant until 2 May 2021, and then afterwards, it reduced to 1/3 of designed output. Generator power and power going to the grid with respect to time and water pressure have been shown in Figures 9 and 10. It has been seen that until 2 May 2021, the power output was $50 \mathrm{~kW}$ approximately, but after this date, the output decreased from $50 \mathrm{~kW}$ to around $17 \mathrm{~kW}$. It is because the water is being used for irrigation purposes, which has priority over power generation. This shows a new community-based business of the Ohito community integrated in agriculture and hydroelectric generation at the local level. 


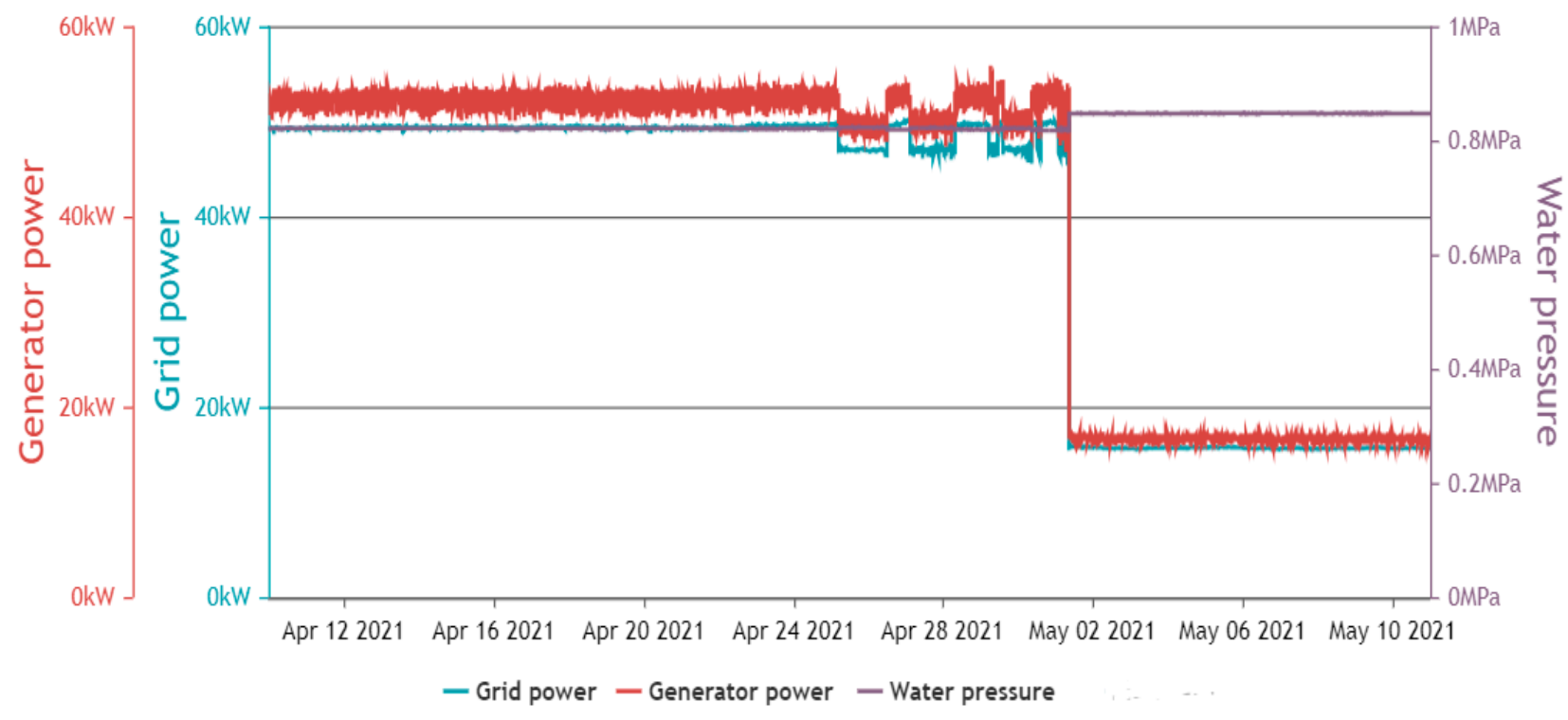

Figure 10. Power generation and supply to grid (Source: Author).

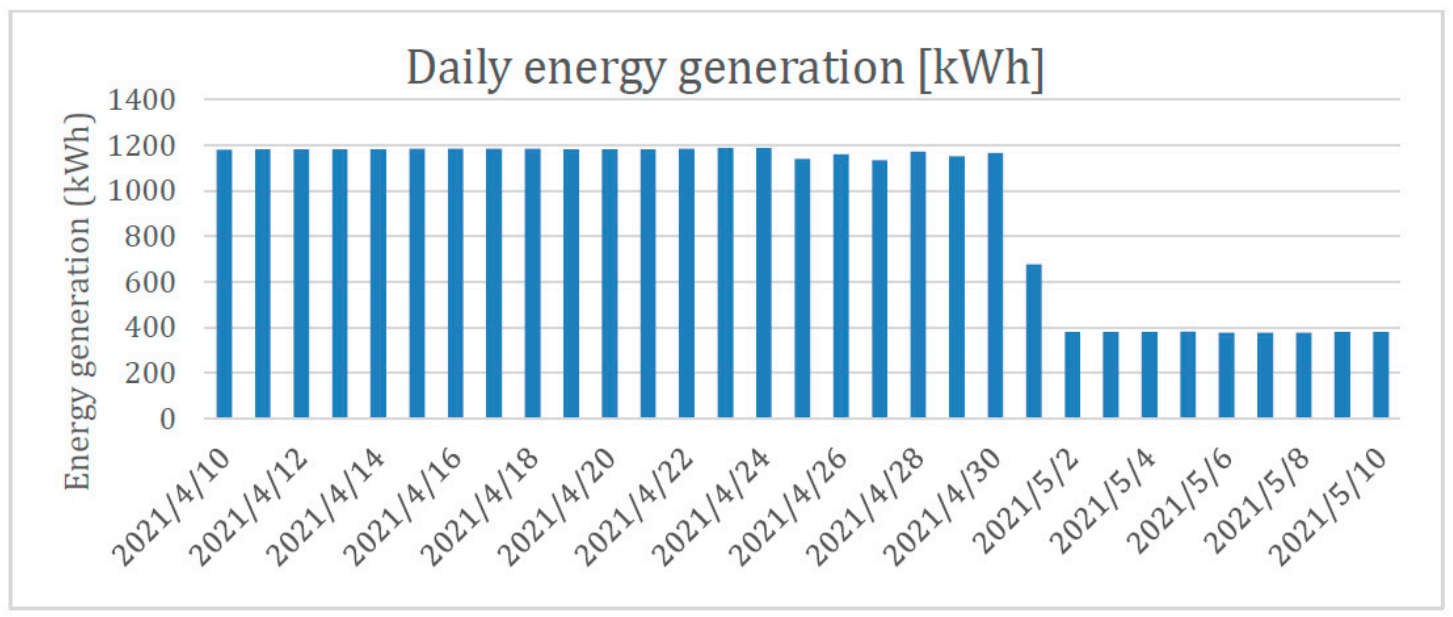

Figure 11. Energy generation per day in kWh. Approximately 1 MWh energy was being generated until 2 May 2021, which has decreased to $400 \mathrm{kWh}$ after starting agricultural activities. The water is used for rice crop irrigation (Source: Author).

From the environmental point of view, the SHP development supports the government's efforts to promote clean energy sources and to carry out its target of SDGs, as an SHP uses water to produce electricity without consuming it. The Ohito SHP uses the existing wastewater in the irrigation channel to produce useful clean renewable energy. In terms of specific SDG, Ohito SHP supports targets 7, 8, 13. With respect to $\mathrm{CO}_{2}$ reduction, since, per kWh of electricity generated from SHP reduces $0.463 \mathrm{~kg} \mathrm{CO}_{2}$, the $350 \mathrm{MWh}$ of electricity generated annually by the Ohito SHP will lead to reduce approximately 162 tons of $\mathrm{CO}_{2}$ per year.

In terms of social contribution, a community-based SHP leads the local growth by providing work to local companies, utilizing local resources and providing a means of engagement to the local young people and a learning opportunity to the students in the community. Like other communities in rural Japan, the Ohito community is also facing ageing, lack of job opportunities, depopulation, etc. Installing this kind of SHP will provide local empowerment and revival of local business. The sole idea to install the Ohito SHP was as follows:

- Improving social welfare, especially improving the living support system.

- Maintenance of roads, irrigations, waterways, inside the community. 
- Maintenance of public halls.

- Utilization of degraded farmland aiming for bamboo grove maintenance and agricultural industry.

However, unfortunately, there was no such work done until the writing of this paper. All the money ( 35,200 USD) is still being kept by the local community. No such investment has been made. Therefore, the direct social impact of installing this plant has not started yet, but there were some indirect social impacts in terms of idea sharing and attracting other communities to install similar SHP projects in respective communities. In addition, it is a source of education for the community people and university students, as they learn not from theory, but by looking at the actual running plant. There is one more hidden important impact. The Ohito community was getting implicit know-hows and community experiences "of the local community, by the community, for the community", by actually operating SHP.

\section{Conclusions}

This paper discussed an SHP development business model in which the local community will become the business owner. It is focused "of the community, by the community and for the community" by discussed a case study of community-based $50 \mathrm{~kW}$ SHP installed in rural Japan. This SHP is one of the best cases of a community ownership SHP model in Japan. The local community is getting approximately 112,000 USD per year by selling the electricity and 162 tons $\mathrm{CO}_{2}$ are estimated to decrease yearly, which will support the achievement of SDGs. Installing this kind of SHP will provide managerial skills to the community, plant operation knowledge, and education to local people. Local communities learn the problem-solving skills and implicit know-how, which lead them to solve the local problem on a community level. Finally, it is concluded that SHP can play a vital role in community development. SHP makes a network of stakeholders, it integrates the local community to the urban stakeholders, and it creates jobs for the local community, which help to engage the local youth to be at home.

In recent times, a localized, independent generation of energy has started and it is growing. An SHP achieves break-even within 8-12 years depending on the investment, but the Japanese government gives FIT for 20 years. This money helps local people to do their community development. The community no longer depends on government subsidies for their development from now on. They use this SHP money for their agriculture land improvement, renovation of local community halls, roads, etc. It gives a means of independence to the local community.

To install more and more SHP, there is a need to make an attractive community-based business model, which includes both rural people and urban stakeholders. This paper has suggested a community owned SHP model, which can be used to install more and more SHP for the local community. It gives ownership to the local community, as the local people identify their problems, install the SHP and do necessary maintenance and management. The income generated by selling electricity is received by the newly established corporation/company composed of all the community members. This association pays the loan to finance companies or banks and utilizes the rest of this money for the development locally. This new community-based action not only works on SHP development, but also the planning to use other natural resources available in the community. It will promote the community independence and self-sustainable to make sustainability.

With a number of benefits, there are some limitations that need to be fixed in the future.

First, the Japanese government is paying a high FIT on SHP, but it still needs to revise. The equipment's and labor costs are high, and so the rate of return becomes slow. If $100 \%$ money is borrowed, the project payback period increases to 10-12 years, which should be below 10 years.

Second, local communities are not always aware and do not have much skill and confidence to manage and operate their natural resources. Therefore, they do not decide to invest the revenue earned by selling electricity. In the future, it is necessary to make a 
plan for the proper utilization of sales revenue. It is necessary to introduce a new player who will take care of this investment to develop the local culture, agriculture land, and community needs. There is a possibility to include university professors or NGOs or the local city office as a coordinator and interpreter. They will take care of revenue earned to use properly for the development of community road, culture, agriculture needs, etc. The community people will decide about the investment area and they will inform them.

Author Contributions: Conceptualization, Z.A. and T.F.; methodology, Z.A.; software, S.H.; validation, T.F., S.H. and Y.W.; formal analysis, S.H.; investigation, Z.A.; resources, T.F.; data curation, Z.A., T.F. and Y.W.; writing-original draft preparation, Z.A. and S.H.; writing-review and editing, T.F. and S.H.; visualization, Y.W.; supervision, T.F. and T.S.; project administration, T.S. and Y.W.; funding acquisition, T.F. All authors have read and agreed to the published version of the manuscript.

Funding: JSPS KAKEN, 18K14538, Tokihiko Fujimoto.

Institutional Review Board Statement: Not applicable.

Informed Consent Statement: Not applicable.

Data Availability Statement: Not applicable.

Conflicts of Interest: The authors declare no conflict of interest.

\section{References}

1. Da Silva, C.G. Renewable energies: Choosing the best options. Energy 2010, 35, 3179-3193. [CrossRef]

2. Neri, E.; Cespi, D.; Setti, L.; Gombi, E.; Bernardi, E.; Vassura, I.; Passarini, F. Biomass Residues to Renewable Energy: A Life Cycle Perspective Applied at a Local Scale. Energies 2016, 9, 922. [CrossRef]

3. Hondo, H. Life cycle GHG emission analysis of power generation systems: Japanese case. Energy 2005, 30, 2042-2056. [CrossRef]

4. Zimon, D.; Tyan, J.; Sroufe, R. Drivers of sustainable supply chain management: Practices to alignment with un sustainable development goals. Int. J. Qual. Res. 2020, 14, 219-236. [CrossRef]

5. Koirala, B.P.; Vaghela, D.; Mitavachan, H.; Kulenthran, R. Opportunities and Challenges of Community Energy Systems: Analysis of Community Micro-hydro Systems in South and South-East Asia (SSEA). In Proceedings of the MES-BREG: Innovating Energy Access for Remote Areas: Discovering Untapped Resources At: University of California, Berkeley, Berkeley, CA, USA, 10-12 April 2014. [CrossRef]

6. Kong, Y.; Wang, J.; Kong, Z.; Song, F.; Liu, Z.; Wei, C. Small hydropower in China: The survey and sustainable future. Renew. Sustain. Energy Rev. 2015, 48, 425-433. [CrossRef]

7. Fonseca, L.M.; Domingues, J.P.; Dima, A.M. Mapping the Sustainable Development Goals Relationships. Sustainability 2020, 12, 3359. [CrossRef]

8. Cheng, H. Utilization of small hydropower resources with promotion of new countryside construction. China Water Resour. 2006, 14, 17-18.

9. Paish, O. Small hydro power: Technology and current status. Renew. Sustain. Energy Rev. 2002, 6, 537-556. [CrossRef]

10. Egréa, D.; Milewskib, J.C. The diversity of hydropower projects. Energy Policy 2002, 30, 1225-1230. [CrossRef]

11. Hansen, M.; Simmons, R.T.; Yonk, R.M. The Regulatory Noose: Logan City's Adventures in Micro-Hydropower. Energies 2016, 9 , 482. [CrossRef]

12. Kosnik, L. The potential for small scale hydropower development in the US. Energy Policy 2010, 38, 5512-5519. [CrossRef]

13. Gorla, L.; Perona, P. On quantifying ecologically sustainable flow releases in a diverted river reach. J. Hydrol. 2013, 489, 98-107. [CrossRef]

14. Dee, N.; Baker, J.; Drobny, N.; Duke, K.; Whitman, I.; Fahringer, D. An environmental evaluation system for water resource planning. Water Resour. Res. 1973, 9, 523-535. [CrossRef]

15. Botelho, A.; Ferreira, P.; Lima, F.; Pinto, L.M.C.; Sousa, S. Assessment of the environmental impacts associated with hydropower. Renew. Sustain. Energy Rev. 2017, 70, 896-904. [CrossRef]

16. Schramm, M.P.; Bevelhimer, M.S.; DeRolph, C.R. A synthesis of environmental and recreational mitigation requirements at hydropower projects in the United States. Environ. Sci. Policy 2016, 61, 87-96. [CrossRef]

17. Watanabe, Y.; Alam, Z.R.R.; Okajima, K.; Yamamoto, S.; Faisal, R.; Kumar, A.; Fujimoto, T. World Small Hydropower Development Report 2019 case studies; United Nations Industrial Development Organization (UNIDO) and International Center on Small Hydro Power (ICSHP): Viena, Austria; Hangzhou, China, 2019; pp. 37-40.

18. Japan's Ministry of Economy, Trade, and Industry. FY2019 Annual Report on Energy (Energy White Paper 2020). Outline. October 2020 and Fifth Strategic Energy Plan; Japan's Ministry of Economy, Trade, and Industry: Tokyo, Japan, 2020.

19. Japan's Ministry of Economy, Trade, and Industry. FY2011 Annual Report on Energy (Energy White Paper 2012) Outline. October 2011; Japan's Ministry of Economy, Trade, and Industry: Tokyo, Japan, 2012. 
20. Fujimoto, T.; Minata, K.; Shimatani, Y. Chugoku Chihou no Syousuiryoku Energy riyou ni miru Shizen Energy ni motozuku Chiiki zukuri no Shisou (In Japanese). Shimaneken Chuusankan Chiiki Kenkyu Center Kenkyu Houkoku 2012, 8, 31-38.

21. Fujimoto, T. World Small Hydropower Development Report 2016; United Nations Industrial Development Organization (UNIDO) and International Center on Small Hydro Power (ICSHP): Viena, Austria; Hangzhou, China, 2016; pp. 415-419.

22. Fujimoto, T.; Kagohashi, K. Community-ledMicro-Hydropower Development Guided by Landcare Approach: A Case Study on a Networking activities of local residents and farmers in Gokase Town, Japan. Energies 2019, 12, 1033. [CrossRef]

23. Data Max Netib-News. Article on Future of Local Communities Connected by Small Hydropower, Published on 05 March 2018. 2018. Available online: https:/ / www.data-max.co.jp/article/2985?rct=machi7 (accessed on 25 April 2021). 